\title{
Travelling to the Margins of Europe
}

\author{
By Ewa Mazierska
}

Fall 2001 Issue of KINEMA

The problem for Europe is to learn how to marginalise itself. (Ien Ang)

CRITICS AND FILMMAKERS alike in recent years drew attention to the crisis experienced by national cinemas in European countries. The UK-based scholar Dimitris Eleftheriotis writes:

This crisis is evident on many levels, from the critical-theoretical to the economic. Indeed the very term 'national cinema' is riddled with conceptual contradictions, and its theoretical, pedagogic and practical usefulness has been repeatedly challenged in recent years. But perhaps more relevant is the realization that shrinking domestic markets have become in most cases inadequate for the financial survival of national films. As a result more and more filmmakers have to rely on state or European funding (and in many cases both) for their productions. This in turn brings into play the contradictions in national and European policy ... and raises dilemmas of criteria and priorities: for example, is funding offered to films asserting difference or those relying on an assumed shared repertory of "European" themes and values ... Coproduction is emerging as an important strategy for the survival of European cinema ... The recent significant shift towards coproduction represents... qualitative leap as the norm will almost certainly become (if it is not already) transnational rather than national production. (Eleftheriotis 2000: 93)

Road films provide an excellent opportunity to explore both the variety and differences of national and regional cultures in Europe, as well as the common 'European identity', of which migration and travelling are often regarded as an important component (see Hall 1992: 46-47), and the areas of potential conflict and domains of co-operation. They also offer a chance to re-examine and renegotiate the relationship between the centre of Europe and its margins, which seems to me a crucial prerequisite for any meaningful discussion concerning a new, united Europe. In practical and institutional terms, road films are also a natural choice for co-production.

In this article I want to examine how Europe and Europeans are represented in two recent films, both of which are European co-productions by German directors: Lisbon Story (Germany-Portugal, 1995), directed by Wim Wenders, and Zugvögel... einmal nach Inari (Trains and Roses, Germany-Finland, 1997), directed by Peter Lichtefeld. Both films focus on a German man travelling from his native country to the geographical margins of Europe: Lisbon and Northern Finland respectively. The principal objective of my examination is to establish the meaning of 'margin' and 'centre' in these films.

\section{Lisbon Story: being European}

Wim Wenders, regarded as one of the most international directors in the world (see Kolker and Beicken 1993: 161-62), refers in Lisbon Story to the idea of a united Europe and of a European citizenship in an overt way. His protagonist Philip Winter, a sound engineer working in films, travels from Frankfurt to Portugal's capital city, musing on his way how Europe is becoming more and more like one country - in contrast to the old Europe, which was divided by wars. This country, he says, is his true homeland; in order to emphasise his Europeanness, he repeats the word 'homeland' in several European languages. Later on, when asked by a barber in Lisbon if he is an American, he answers: 'European', further reassuring us about the strength of his European identity. The part of Europe that Philip crosses, comprising Germany and France, is indeed peaceful. However, other regions, such as the Balkans, Northern Ireland and Turkey, are still divided by wars. One can assume that these troublesome areas do not constitute 'Winter's Europe', a suspicion confirmed by the choice of languages that he uses to express his European patriotism: there is no Turkish, Irish or Serbo-Croatian amongst them.

On his way to Portugal Philip observes that European borders still exist, but that they no longer matter. Jokingly, he addresses the non-existent or indifferent border guards, asking: 'Don't you want to see my passport or check what I am smuggling in the boot of my car?'. His proclamation of the 'United State of Europe' is supported by images of vehicles swiftly passing border controls, or crossing borders between countries without any controls at all, and marked only by a sign with the country's name - such as the 
frontier between Spain and Portugal. Borders, as David Sibley observes, are typically erected to defend oneself against outsiders, as well as to confirm and strengthen the differences between 'us' and 'them'. They can provide security and comfort, as well as lead to an experience of constraint and rejection - depending on who constructs the borders and why (see Sibley 1995: 32-48). Accordingly, the informality of national borders in the part of Europe depicted by Wenders suggests that states and nations do not need to defend themselves against the threat of the other, or to pronounce their difference from the surrounding states and nations.

The landscape that Winter passes changes, becoming more rocky and dramatic, but the townscape and 'motorway-scape', with the same road signs, petrol stations and types of cars, remain the same. Winter uses the long journey to Portugal to learn Portuguese, and seems to do it more from interest and respect for the country he visits, than out of necessity. Because he goes to Lisbon to meet his friend Friedrich Monroe, an American director who asked him for help in finishing his film, he can assume that he will not even need Portuguese to communicate when performing his job. However, the problems that Winter encounters on his journey with his broken-down car, as well as the disappearance of Friedrich before he even comes to Lisbon, demonstrate the great usefulness of his knowledge of Portuguese.

For the remaining part of the film Philip explores Lisbon and records sounds for a silent film about this city that Friedrich Monroe started to shoot there to commemorate the 100th anniversary of cinema, but that he eventually abandoned. Gradually, Philip becomes fascinated with Lisbon and Friedrich's film. He also becomes charmed by Teresa, a singer in a group named Madredeus, whose songs were meant to be used by Friedrich as the soundtrack of his film. Looking like a model Mediterranean beauty, with long, black, simply done hair, black eyes, clad in a dark long dress, and singing songs inspired by Portuguese folklore, Teresa can be regarded as a symbol of Lisbon (and perhaps of the whole Portugal), and Philip's enchantment with her is symbolic of his love for this city and country.

Lisbon is placed on the geographical edge of Europe - it stands at the westernmost point of the European mainland. It is also represented by Wenders as politically and economically marginal, conforming to the view that geographic marginality is typically a mark of being a social periphery (see Shields 1991: 3). This political and economic marginality relies on Lisbon's resistance to values such as progress, speed, pursuit of money, and efficiency - values that, albeit primarily associated with America, have become increasingly widespread and dominant in large European cities. On the contrary, Lisbon looks like a place that has hardly changed since the nineteen century. For example, the principal means of transport used here by people are old-fashioned tramways. We also see a wandering knife-grinder on an ancient bike and women hand washing clothes in basins attached for this purpose to the front of their small cottages. The way of life is very relaxed and communal, with neighbours knowing each other well and people stopping the tram drivers in order to ask for directions. Even the clothes hang outside windows or on ropes over the narrow streets, something more appropriate for a village than for a large city. Along with the almost non-existent traffic, the communal lifestyle makes the inhabitants of Lisbon feel very safe. Unlike in contemporary metropolises, which are anonymous and dangerous as a result of crime and drug abuse, children here are not afraid to play in the streets or to approach strangers. The village-like character of Lisbon is also highlighted by Friedrich and Philip, who have the habit to leave unlocked their flat and the editing studio where they keep their valuable equipment, without any fear of burglary. Furthermore, Lisbon is depicted as a city that remembers, respects and makes use of its history. The importance of history lies in the memories of the past that old inhabitants recollect during their conversations with Winter, and in the prominence and functionality of the old buildings, such as the ancient aqueducts and the large areas of excellently-preserved old cottages. It is worth mentioning that most of the film was shot in Lisbon's Old City. The new estates with high-rise skyscrapers are shown only at the end of the film, and it is suggested that they are not typical for Lisbon. Philip, who finds Friedrich there, amongst ugly blocks of flats, advises his friend to leave this neighbourhood immediately. In addition, Lisbon's history is alive in the songs written and performed by Madredeus.

When all these features of Lisbon are recorded by Friedrich for his silent movie, in sepia colour, with the same antiquated camera that Buster Keaton, Dziga Vertov and other masters of early cinema used, the city looks even more as if frozen in time. The very fact that Friedrich Monroe (and Wim Wenders) chose Lisbon to make a film about the old world and to commemorate cinema's jubilee, suggests that they found Lisbon a quintessentially nineteenth-century town, more so than Paris or Berlin (not to mention any American city). 
The suggestion is confirmed by Wenders in one of the interviews that he gave in connection with Lisbon Story (see Colusso 1998: 76). It is worth mentioning that, upon his return from America, Jean Baudrillard observed that Paris (and by extension Europe, understood as the Old World) gave him the impression of living in the nineteen century (see Baudrillard 1988: 73). It could be argued that for Friedrich and Wenders Lisbon, by being more nineteenth-century than Paris, is also more European than the continent's geographical centre, in spite of being situated at the periphery of Europe. Wenders himself in an interview has referred to Lisbon as a metaphor for Europe (see Colusso 1998: 79).

Lisbon Story discusses at least three facets of the opposition marginality/centrality, with reference to Europe: geographical, political/economic, and cultural. At the same time as being depicted as marginal, in both geographical and political/economic terms, Lisbon is represented as central to Europe from a cultural point of view. Moreover, it seems as if, according to Wenders, it is precisely because of its geographical and political marginality that Lisbon remained true to itself and, consequently, to its nineteen-century, European character. Such an exaltation of the European geographical and political margins should naturally lead to a criticism of the old European centre (wherever this centre is placed). Although the idea of the old centre's inferiority is not openly discussed in the film, it is nevertheless implicitly conveyed by the suggestion that in the twentieth century central Europe took a wrong turn, both politically and culturally, first by engaging in wars and secondly by imitating America. ${ }^{(1)}$

The discovery of Lisbon's nineteen-century character and the making of a silent film about the city are meant to awaken nostalgia for the cultural (if not political and social) past, as well as for old cinema. In the opinion of Friedrich, an opinion that Winter shares, and that can be identified with Wenders' own stance, old movies have an innocence and purity that contemporary cinema lacks. Friedrich complains that in contemporary times images have lost their natural connection with the world, and are used instead to sell products. After weeks of shooting with his old camera, he abandons the idea of a silent film about Lisbon and embarks on a new project, which consists of shooting without really operating a camera: he hangs it on his back, allowing it to record images at random. Neither does he review afterwards the footage he has produced in this way. He claims that such non-reflexive shooting is the only way to make a film that will reflect reality, in this case - Lisbon, truthfully, and not as a director or anybody else conceives it. Winter is not so radical in his attitude to filming, but he deeply dislikes video - he even calls the children whom he befriends in Lisbon 'vidioten' (video-idiots) because they continually use their video cameras.

Germany is never mentioned by Winter. It feels as if he traded his German identity (if he ever had one) for a European personality. It also looks as if Winter - played by Wenders' regular actor Rudiger Vogler, who also impersonated the main characters in Im Lauf der Zeit (The Kings of the Road, 1976) and Alice in den Städten (Alice in the Cities, 1974), in which he was also called Philip Winter - is to a certain extent a product of, to use Wenders' own phrase, the 'American colonisation of the German subconscious'. For example, on various occasions he pronounces his surname as if it was an English name, and prefers to read parallel texts of Portuguese poetry in English rather than in German.

Bridges, roads and various means of transport, such as trains, cars, and ships, feature prominently in Lisbon Story. They emphasise that Lisbon is an important place of cultural encounter and exchange. There are also frequent images of the water surrounding Lisbon and of aqueducts, and the characters discuss the importance of water for the city. Even one of Madredeus' songs is dedicated to the river Tagus. As Dimitris Eleftheriotis observes,

Water is a material and visual manifestation of fluidity and ... fluidity involves first and foremost a renegotiation of identity. This entails a restructuring of the relationship between similarity and difference that supports any identity. In a geographical sense water seems to reproduce this dynamic relationship between similarity and difference, union and separation: seas and rivers are not only physical frontiers and markers of national borders, but also routes of communication linking and connecting ports, peoples and cultures (Eleftheriotis 2000: 999-100).

In Wenders' film water might refer to both Lisbon's and Portugal's openness to various cultural influences, as well as to the 'flooding' of other peoples and countries with their own culture. It might also refer to Winter's own position as a man who in Lisbon 'renegotiates' his identity. 
Looking at Tagus and the Atlantic Ocean surrounding Lisbon, it is difficult not to think about the city's colonial past. It is worth remembering that Lisbon was both an object of foreign invasions and an invader. Captured by the Moors in the eighth century, in the twelfth century it was conquered for Christendom by Alfonso Henriques, assisted by a Christian crusade of Normans, Flemish and English. With the opening of the sea route to India and the discovery of Brazil, Portugal became very rich and powerful, both in Europe and on a global scale. It was also from Lisbon that the Invincible Armada sailed in 1588 (see Bradford 1973: 24-54). Interestingly, the issues of colonialism and post-colonialism, and of Lisbon's multiculturalism, are almost completely erased from Wenders' film. There is no reference to Lisbon's Moorish past, and the only allusion to Lisbon's connection with the old colonies (which appears accidental and insignificant) is when Philip asks Teresa about her artistic tour of Brazil. Moreover, apart from Friedrich and Winter, no incomers feature in Lisbon Story. One may suspect that the memory of the 'ultra-European' Lisbonians heading for South America to kill and exploit the natives, as well as of any tensions between Christians and Muslims living in Lisbon, will not suit the film's portrayal of a civilised, peaceful and presumably Christian Europe. Lisbon Story's oversight, or perhaps even denial of Portugal's, and by extension, of Europe's colonialism, coupled with the nostalgia for an ultra-European, nineteen-century past, could also be viewed in the context of Wenders' belonging to the New German Cinema, in which the only colonisation mentioned was the American cultural colonisation of Germany after the Second World War (see Elsaesser 1989: 228-232).

Wenders shows us that both Friedrich and Philip fell under the spell of Lisbon and of Teresa. The best testimony to Philip's love of the city is the fact that it is thanks to him that the silent film about Lisbon will be completed even after Friedrich decided to abandon this project. However, I will argue that, in spite of Winter's enchantment with Lisbon, his learning Portuguese, and his longer-than-planned permanence in this city, he remains a tourist, keeping a safe distance from the place he visits. Firstly, his very interest in the historic Lisbon, at the expense of the contemporary city, betrays a typical tourist attitude. In particular, Philip is reluctant to view the images that his young friends shot with their video cameras, and that reflect their everyday life and what they see around them, such as some school scenes. This unwillingness partly results from the previously mentioned distaste that Winter has for the medium they use, but also partly from a lack of interest in the reality that they try to immortalise. Secondly, his enchantment with Teresa does not lead to any true love or romance, or desire to live together, which was even lamented by some critics (see Gansera 1995: 37). He admires her as a beautiful object, in the same way as a tourist admires a palace or a church - without planning to take it home, or at very most only in the form of an image on a postcard. The same can be said about Monroe. His way of filming Lisbon, using a camera placed on his back, suggests as much his desire to get a true image of the city, as his unwillingness to explore it, to have any personal contact with it. His distance from Lisbon and his enclosure in his private obsessions is also signified by the place where he lives: a small, strange car at the outskirts of Lisbon. Furthermore, Friedrich uses as his guide to Lisbon a boy who is mute, as if he was afraid that an articulate Lisbonian could destroy his preconception of the city. The whole film can be regarded as a kind of tourist guide to Lisbon and a praise of tourist pleasures.

Winter's unwillingness to commit himself seriously to his love for Teresa and for Lisbon is typical for Wenders' characters and the director's own Weltanschauung, which was accurately summed up by Robert Phillip Kolker and Peter Beicken with the words: 'He makes homelessness a virtue, an aesthetic' (Kolker and Beicken 1993: 161). This unwillingness can also be interpreted as a testimony to Winter's prioritising his Europeanness over any national or regional identity. This is because identity can only be constructed through demarcation of oneself in relation to some other. As Paul Gilroy observes, 'nobody ever speaks of human identity' (Gilroy 1997: 301). I will suggest that there are two principal 'others' in relation to Winter's pan-European identity: one is American culture, the other are European national cultures. Consequently, to remain a true European, Winter can not allow himself to identify too strongly or exclusively with any particular European culture. It is worth mentioning here that strong nationalism and patriotism goes hand in hand with lack of enthusiasm and sometimes even with open hostility, as in the case of Britain, towards such quintessentially pan-European institutions as the European Parliament in Brussels or the Euro (common European currency). I will also suggest that patriotic feelings towards Europe are still a rarity amongst ordinary European citizens, which might explain why Europeanness is rarely represented or projected in 'high art' (Lisbon Story might be regarded as an attempt to change this but, as some reviewers observed, it is not entirely successful). On the whole, to use Godard's phrase, today's Europe is styleless (see MacCabe 1992: 100), although this might 
change over time, with a growing number of people willing to assert and project their European identity in art.

The oversight of Portuguese colonialism and of past and present multiculturalism, as well as the lack of interest on the part of Wenders and his protagonist for contemporary Lisbon, significantly narrow the parameters by which the discussion of Europe and its margins is conducted. Such omissions are regrettable, as the issues are crucial for any meaningful discussion about European margins and European identity. It could be said that, although nominally Winter and Wenders reached the margins of Europe, metaphorically they did not travel far.

\section{Trains and Roses: becoming Finnish}

Trains and Roses deals with many of the issues that Wenders discusses in Lisbon Story, but does it in a more discreet way or, as one might say, in the shade of the narrative. The film tells the story of a lorry driver from Dortmund, named Hannes Weber, whose hobby is to memorise train timetables. His ambition is to win a world competition of this activity, which takes place in Inari, in Lapland. In order to be able to attend the event, he approaches his new boss to obtain from him a week of unused holiday. The director, however, who was appointed to 'rationalise' the truck company, which in practice means to make many employees redundant, fires him, regarding his wish to go on holidays as a sign of his insufficient commitment to work. Weber, who had not had time off for several years, finds the attitude of his boss unacceptable; he punches him and leaves for Finland. Several hours later the boss is found dead in his office and Hannes becomes the prime suspect in the murder investigation. The police and the border security of several countries are informed about his crime, and they try to stop him on his way to Inari. This international and costly operation, however, proves unsuccessful. In the end Stefan, the main detective on the case, flies to Finland to arrest Hannes only minutes before the competition starts but, begged by him, decides to allow him to take part in the event. Hannes loses by a very small margin, but is allowed to walk free, as during the competition the detective discovers that the true killer of Weber's boss was in fact his secretary.

The narrative of Hannes's journey from Dortmund to Inari, as Winter's journey from Frankfurt to Lisbon in Wenders' film, allows the director to examine the relation between national and European identities and cultures. Hannes is portrayed as a very un-German German. Instead of listening to German music, his favourite singer is Italian Adriano Celentano; he does not like football, which is a favourite pastime in his native Dortmund, and in fact his mate from work has to go to a Borussia match by himself; he even avoids drinking beer when in his hometown. Neither does Hannes' flat show any sign that his owner is German. It is furnished in a most basic way and looks more like an information office at a railway station than like a home, with maps of railway connections, train timetables and a large railway clock hanging on the wall. Even Hannes' job as a truck driver, which involves spending a substantial part of his life travelling, presumably also abroad, suggests a lack of strong national and regional identity.

Dortmund is depicted by Lichtefeld as a nondescript, monotonous and rather ugly town. The less attractive sides of buildings are usually shown: the back of supermarkets and of a stadium, a truck depot and identicallooking blocks of flats. The camera never shows an overview of the city, but only uncovers small portions of streets and locales, giving the impression of Dortmund being fragmented, a 'locus of alienation'. It could be argued that such a place is hardly conducive to having patriotic feelings. Later on, when Hannes on a train to Hamburg writes a postcard to his friend entitled 'Greetings from beautiful Dortmund', it looks like a bad joke.

Hannes' obsession with timetables, particularly his efforts to find the shortest routes between European cities, can be interpreted as a sign that being a citizen of Europe matters for him more than being German. On the way to Inari he confesses that he has the ambition of becoming a railway expert and of working for the European Union to develop the fastest European railway transport possible - a system that will be unified and standardised, and thus replace the current national, fragmented railways. Although he does not say it, it is not difficult to guess that his project would bring Europeans closer together, at the same time as making their lives faster and more efficient. Lichtefeld also shows that Europe is already well connected and co-operates in many areas, such as trade (legal and illegal), policing and border control. For example, it takes only minutes for Stefan, who investigates the murder of Hannes' boss, to inform the border controls and the police in Sweden and Finland that the principal suspect is trying to cross their frontiers. On the 
other hand, in spite of the co-operation, people manage to cross the borders illegally and criminals succeed in escaping international police, confirming the widespread opinion (particularly strong in Great Britain) about European bureaucracy and inefficiency. Lichtefeld also shows, perhaps unintentionally, that there are some shortcomings in living in a unified and standardised Europe, such as having similar food being served on the trains and on ferries in Germany, Sweden and Finland.

The railway in Trains and Roses can be interpreted as an epitome of Continental Europe, understood as a place where states still largely own and control the industry, and where people are encouraged to use public transport in order to avoid road congestion, to travel more safely and comfortably, and to protect the environment. In this respect, the train might be contrasted with the private car, which symbolises America as an individualistic country, dominated by corporations and unconcerned about the natural environment. It also encapsulates the distinctiveness of European road cinema, as in American films the characters almost always travel by car or by motorcycle. Trains in Lichtefeld's film work almost perfectly: there are no delays, compartments are clean and well equipped, conductors are polite, there are no vandals onboard, and the tickets are reasonably priced. Not each European country, though, has such a perfect railway system. An example is the British one, ineffective both in reality and in the way it has recently been depicted by the media. Privatised by the Major government, which, in common with the Thatcher administration, was greatly influenced by American-style economies, extremely fragmented, lacking funds, expensive, unreliable and unsafe, the British railway is justly regarded as one of the worst in the world. It could even be suggested that if the timetable competition had been organised in Leeds, Glasgow or Bristol, instead of Inari, many participants would probably have missed it.

Hannes feels much more at home on the trains and on the ferry, than in his company office or in his Dortmund flat. At work he feels awkward and shy, unable to express himself adequately or to fight his corner. Moreover, he is oblivious to what people tell him and think of him, and even does not notice the attention of a young woman who works in a supermarket. When on a train, however, even if in a foreign country, he is a man nobody can fool. He knows the precise prices of different seats and sleeping compartments, he knows how to defend his territory when somebody tries to steal his place and, of course, he knows the fastest train connections. Moreover, although Hannes is regarded by his fellow employees as a reserved man, even as a loner, during the journey he reveals well-developed social skills. He becomes friendly with a string of different people, including a conductor involved in money counterfeiting and a Finnish woman, named Sirpa, who lives in Helsinki, but dreams about cultivating roses in a Finnish village. In the end he falls in love with her and it is suggested that he will remain in Finland to work with her on a rose plantation.

Nationality plays little part in the contacts Hannes makes on his way to Inari, as neither he nor his fellow travellers mind whom they talk to. For example, the Finnish couple whom Hannes meets on the last train enjoy the fact that they are all professional drivers: sharing the same type of work is for them more important than coming from the same country. Moreover, the man says that it does not matter where one lives or what nationality one has; what is really important is 'having a good woman on one's side'. These words, although Hannes' interlocutor does not know it, also refer to Hannes, who on his way to Inari fell in love with Sirpa. Speaking different languages is hardly a problem in trans-national connections, as everyone shown in Trains and Roses know at least two languages: their own and English. The majority of Finns also speak fluent German and Swedish. They learn foreign languages not simply out of necessity, but out of curiosity, to find out about foreign cultures, as revealed in the episode on a train when the Finnish train driver switches on the radio tuned into a German station to demonstrate how she learnt almost perfect German.

The film's author also draws our attention to the fact that there are differences more important than those between nations, such as between city and country, as well as between people who put profit first and those who cherish love, friendship and a balanced life more than economic success. For example, Sirpa abandons her Finnish boyfriend because he does not want to move to the country, where she inherited the rose plantation. We never see the boyfriend as he is so busy with his work that he hardly visits their flat, only leaving messages for Sirpa on his computer or on their answering machine. Neither does he look after Sirpa's favourite roses: on her return from Germany she finds them in their large Helsinki flat, all withered. By contrast, it is suggested that Hannes will be happy to live with Sirpa close to nature, as he greatly enjoys walking with her in the forest and exploring Lake Inari in Lapland. The best indication of him embracing her values is his behaviour at the competition. Asked about the best route from Munich to Inari, Hannes 
does not answer by giving the details of the fastest route, but of the longest one, which Sirpa described to him the day before as her favourite. This is a route in which the traveller reaches his destination in the morning, relaxed and satisfied with his journey. As a result, Hannes loses the competition beaten by one Ms Higgins (probably an American), who answered by providing the fastest route, but wins the heart of Sirpa, demonstrating to her his good memory of her travel tips and his faithfulness to her values. The film's author fully endorses the rural, even marginal lifestyle that Sirpa hopes to enjoy once she moves to the rose farm, and that Hannes discovers on his way to Inari, and condemns the city culture based solely on financial success as inhuman. I will also argue that, by doing so, Lichtefeld promotes the idea of a Europe that does not want to go the American way, since the values that Sirpa opposes are even more widespread in the USA than in any European country.

The scenery significantly changes during the course of the film - Germany looks extremely industrialised, urbanised and grey, with hardly any signs of nature, whereas Finland is sparsely populated, only lightly touched by civilisation and, contrary to stereotypes, rather colourful, with green, yellow, and brown leaves on many different types of tree. The Finnish landscape is shot with a long take and a bird's-eye view is often used, to allow the viewer to contemplate the magnificent landscape. The towns, however, look very similar along the whole route between Dortmund and Inari, with almost identical railway stations, blocks of flats and large corporation buildings standing in prominent positions in Hamburg, Stockholm and Helsinki. Thus, the main differences between Germany and Finland rely on the fact that large towns are a rarity in Finland, whereas Germany is very urbanised.

On many occasions Finland is described as being located on the margins of Europe: the characters simply say that 'Finland is the end of Europe'. The northern regions of Finland, Lapland, are also depicted as playing a crucial role in defining Finnish national identity. Attention is drawn to such extreme phenomena as Lake Inari, the most northerly lake in the world, the austere climate and the long periods of complete winter darkness in Lapland, which, as Sirpa puts it, 'lie heavy on the soul', making people sleepy, slow and inactive. The Finns are portrayed by Lichtefeld as very friendly, relaxed, but also self-deprecating and slightly sad. Testimony to their dead-pan sense of humour is a scene that takes place on the border between Sweden and Finland. The Finnish border guards receive a photograph of Hannes by fax, but do not identify him amongst the passengers leaving a ferry and comment that not even a fool would decide to flee to Finland. They quickly lock up their checkpoint, without ensuring that all the passengers have crossed the border, allowing Hannes, who overslept the ferry's arrival, to enter Finland unchallenged. This episode bears strong associations with the films of Aki Kaurismäki, probably the best known Finnish film director both at home and abroad. Another reference to the cinema of Kaurismäki is the appearance of Kati Outinen, who plays a taciturn Finnish woman, married to the truck driver whom Hannes meets on a Finnish train. The reference to the work of Kaurismäki can be interpreted as proof that, as Timothy Corrigan observes, contemporary road cinema deals more often with images, with 'simulacra', than with reality proper (see Corrigan 1991: 152). In my opinion, however, the reference to Kaurismäki rather suggests the desire on the part of the director of Trains and Roses to depict Finnish people and their culture from the perspective of the insider, rather than that of the uninformed tourist.

The construction of Finnish national identity around the 'Lapland discourse' is reminiscent of the construction of Canadian national identity around the myths of the Arctic and Sub-Arctic (see Shields 1991: 162-206). In spite of the fact that only a small proportion of Finns and Canadians actually live in the North, in both cases the Northern periphery plays a crucial role in establishing what being a 'true' Finn or Canadian means. As Rob Shields writes,

The myth of the 'True North Strong and Free' has been appropriated as one symbol of specific Canadian nationalistic discourse which, although not completely hegemonic, attempts to reconcile regional viewpoints. This myth resides within an oppositional spatialisation whereby Southerners construe the North as a counter-balance to the civilised world of the Southern cities, yet the core of their own, personal, Canadian identity ... The 'True North Strong and Free' is a perverse case of building a cultural identity from both sides of the equation civilised - uncivilised or culture - nature: of defining a dichotomy and then reappropriating elements which are often rejected because the dualism becomes associated, metaphorically, with other black and white categories such as good - bad ... Such a dualism provides a foundation for Canadian nationalists because it 
provides the possibility of setting a 'Canadian nature' (The 'True North') off against 'American mass culture' entirely originating, or so we are asked to believe, south of the border (Shields 1991: $163)$.

Similarly, the 'Finnish national character', equated with 'Lapland character' in Lichtefeld's film (as well as in the films by Aki Kaurismäki), is set off against metropolitan Finnish culture, epitomised by the lifestyle of Sirpa's boyfriend and condemned as fake and inhuman.

Although Finland is at the end of Europe and apparently content with its peripheral position, the organisation of the first world timetables competition in Inari suggests that the country tries and succeeds, albeit on a small scale, to be at the centre of Europe, or even of the entire world. It also proves to be more innovative than many of the more central and powerful countries. The actual competition also makes the viewer realise that Europe extends much further than the borders of Western Europe or of the European Union, as places such as Constanza in Romania and towns in the ex-Soviet Union are mentioned. The competition is, however, very modest and low-key, contrasting with many other European contests and festivals, renowned for their often kitsch pomp.

Water plays an even more important role in the setting and narrative of Trains and Roses than in Lisbon Story. A substantial part of Hannes' journey involves crossing water or travelling near water. Very often characters comment on the beauty of Finnish lakes and their importance for the country's mythology, for example the holy island of Ukonnkivi, which emerges from Lake Inari. The more Hannes learns about the waters of Finland, both through listening to the stories which Sirpa tells him, and by walking around Lake Inari, the more he is enchanted by the Finnish landscape and culture and by Sirpa, and the more distanced he becomes from his own life back in Dortmund, and even from his ambition of winning the contest. Hannes' change of identity, from German to Finnish, from metropolitan to rural, is much more profound than that of Winter in Lisbon Story who, unlike Hannes, had no desire to learn what Madredeus sang about. It could also be suggested that in Trains and Roses to be a cosmopolitan and tolerant European is not an end in itself, but only a stage on the route to becoming a person who prefers another culture to the one in which he was brought up. Conversely, one can hardly imagine a person of nationalistic views falling in love with Sirpa and Inari as easily as Hannes. At the same time, to smooth the process of Hannes' 'becoming Finnish', Lichtefeld represents Sirpa as completely at ease with German culture. Not only does she speak fluent German, but it is also suggested that she lived in the country for some time. She even takes precisely the same route from Dortmund to Helsinki as Hannes does. Moreover, in spite of Hannes being only an unemployed lorry driver, both Hannes and Sirpa are depicted as typical Westerners who live a reasonably comfortable and safe life, unlike many of the immigrants from Eastern Europe, Africa or Asia, who in their native countries suffered poverty and fear of political or religious persecution. In common with Lisbon Story, the issue of crossing the European borders by non-Western Europeans and the encounters between the citizens of the European Union and other Europeans is not touched on at all.

The attractiveness of 'marginal' Finland for Hannes, in common with the attractiveness of Lisbon for Philip Winter in Wenders' film, but to an even greater extent, results from the fact that the periphery possesses a distinctive culture, which the civilised, industrialised, urban centre of Europe, from which their travels originate, is perceived to lack. The conviction can be treated as part of a larger discourse, concerning the decline of the West as a result of globalisation. John Tomlinson, referring to the work of Anthony Giddens and Zygmunt Bauman, writes:

Although the process of 'globalising modernity' may have begun in the extension of Western institutions (capitalism, industrialism, the nation-state system), their very global ubiquity now represents a decline in the differentials between the West and the rest of the world. In a sense the West's 'success' in disseminating its institutional forms represents a loss of its once unique social/cultural 'edge' (Tomlinson 1999: 172).

Consequently, one can expect that, as Europe becomes increasingly more Westernised and 'global', these parts of the Old Continent, which resist the forces of globalisation, even at the cost of remaining backward and parochial, will become all the time more important from a cultural point of view.

In common with Wenders, Lichtefeld advocates travelling both in the literal and metaphorical sense. All 
the film characters who embark on a journey benefit from it immensely. This refers not only to Hannes and Sirpa, who meet each other on a train, but also to Stefan, the policeman who investigates the murder of Hannes' boss. We meet him as a man who sees no world apart from his work - obsessive, intolerant, difficult to co-operate with. However, learning about train timetables and eventually going to Finland changes him into a 'softer', more considerate and sensitive person. After finding Hannes in Inari and discovering that he did not commit the murder, he decides to prolong his sojourn in Lapland. One can imagine that in future he might even succeed to Hannes in the train timetable competition.

Zygmunt Bauman observes that 'If the modern "problem of identity" was how to construct an identity and keep it solid and stable, the postmodern "problem of identity" is primarily how to avoid fixation and keep the options open' (Bauman 1996: 18). Consequently, by emphasising the advantages of travelling, understood as changing places and personalities, Lisbon Story and Trains and Roses can be regarded as films which not only represent, but also advocate a postmodern lifestyle.

\section{Conclusions}

Both films discussed in this article, Lisbon Story and Trains and Roses, show the closeness of people living in different parts of Europe: the centre and the margins. They also concentrate on the beauty, allure and cultural richness of the periphery of Europe, which seem to surpass the attractiveness of the centre. These two factors result in the evolution of the principal characters, who fall in love with the culture of Lisbon and Lapland respectively, and with women who epitomise these places. However, only in the case of Hannes in Trains and Roses is it a true love, paired with a commitment to stay together 'on the margin'.

At the same time, I argue that both Wenders and Lichtefeld refer to a rather narrow concept of Europe, namely the relatively affluent Western Europe, populated by people who have lived there for many generations: ethnic Germans, Portuguese and Finns. Hence, although Germany is the most multiethnic country in the whole European Union (something that is well documented by the German cinema of the last decade), Wenders and Lichtefeld avoid the issue of 'renegotiating identity' inside the borders of Germany, between ethnic Germans and, for example, Turks, Kurds, ex-Yugoslavians or Poles. In Trains and Roses there is even no token presence of immigrants on the trains to or from Hamburg, in spite of Hamburg having one of the highest proportions of immigrants in the whole of Germany.

Literally and metaphorically, the films explore the margins of Europe from inside. They do not interrogate Europe from the point of view of those who are beyond the frontiers of Western Europe, either physically or as a result of belonging, for example, to an ethnic or religious minority, or of living in poverty. Accordingly, crossing national frontiers in these films and reaching the margins of Europe do not involve any dramatic change of identity on the part of the characters.

I will suggest that, by excluding such issues as multiculturalism, ethnic tension inside Western European countries, Europe's colonial past and its legacy, and many other problems summed up by the phrase 'Fortress Europe' (see Cohen 1994: 181-183), as well as, particularly in the case of Wenders' film, applying nostalgia as a narrative technique, they perpetuate a rather unrealistic and conservative vision of Europe, as self-satisfied and culturally superior to its main rival - the USA. To put it metaphorically, these films show that Europe is discovering its margins, but still needs to learn, as Ien Ang put it, 'how to marginalise itself, to see its present in its historical particularity and its limitedness, so that Europeans can start relating to cultural "others" in new, more modest and dialogic ways' (Ang 1992: 28).

\section{Notes}

1. Wenders is not the only European filmmaker who recently drew attention to Europe's past mistakes and the consequences for the issue of marginality/centrality. A similar idea is conveyed in Patrick Keiller's London (1994), where the author claims that London and the whole of England took a wrong turn in the nineteen century, where the governments' fear of the mob and of socialism led to the underdevelopment of the centre of London and the over-importance of the suburbs. The result is a 'civic void' in the centre of London and, consequently, the whole England. 


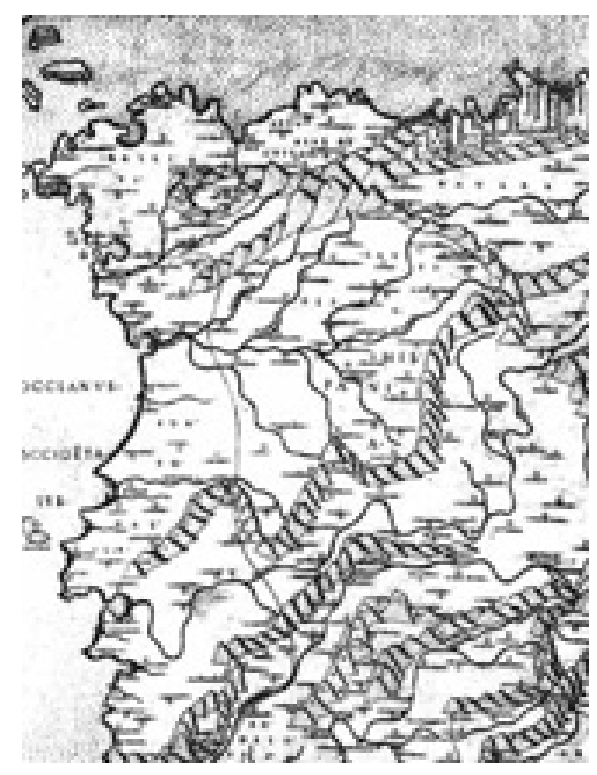

Figure 1: A margin of Europe (Hispania, 15th century)

\section{References}

Ang, Ien (1992). 'Hegemony-in-Trouble: Nostalgia and the Ideology of the Impossible in European Cinema' in Duncan Petrie (ed), Screening Europe (London: BFI), pp. 21-31.

Baudrillard, Jean (1988). America (London: Verso).

Bauman, Zygmunt (1996). 'From Pilgrim to Tourist - or a Short History of Identity' in Stuart Hall and Paul du Gay (eds.) Questions of Cultural Identity (London: Sage), pp. 18-36.

Bradford, Sarah (1973). Portugal (London: Thames and Hudson).

Cohen, Robin (1994). Frontiers of Identity: The British and the Others (London: Longman).

Colusso Paolo Federico (1998). Wim Wenders. Paesaggi luoghi città (Torino: Testo\&Immagine).

Corrigan, Timothy (1991). A Cinema Without Walls: Movies and Culture After Vietnam (London: Routledge).

Eleftheriotis, Dimitris (2000). 'Cultural difference and exchange: a future for European film' in Screen, vol. 41, 1, Spring 2000, pp. 92-101.

Elsaesser, Thomas (1989). New German Cinema (London: BFI).

Gansera, Rainer (1995). 'Lisbon Story' in epd Film, 5, p.37.

Gilroy, Paul (1997). 'Diaspora and the Detours of Identity' in Woodward, Kathryn (ed) Identity and Difference (London: Sage), pp.301-343.

Hall, Stuart (1992). 'European Cinema on the Verge of a Nervous Breakdown' in Duncan Petrie (ed), Screening Europe (London: BFI), pp. 45-53.

Kolker, Philip Robert and Beicken, Peter (1993). The Films of Wim Wenders. Cinema as Vision and Desire (Cambridge: Cambridge University Press).

MacCabe, Colin (1992). 'Jean-Luc Godard in Conversation with Colin MacCabe' in Duncan Petrie (ed), Screening Europe (London: BFI), pp. 97-105.

Shields, Rob (1991). Places on the Margin (London and New York: Routledge). 
Sibley, David (1995). 'Border Crossing' in his Geographies of Exclusion (London: Routledge), pp. 32-48.

Tomlinson, John (1999). 'Cultural globalisation: placing and displacing the West' in Hugh Mackay and Tim O'Sullivan (eds.) The media reader: continuity and transformation (London: Sage), pp. 165-177.

\section{Author Information}

Ewa MAZIERSKA is Professor of Contemporary Cinema at the Department of Humanities, University of Central Lancashire. Her publications include Masculinity in Polish, Czech and Slovak Cinema, Roman Polanski: The Cinema of a Cultural Traveller, Women in Polish Books (with Elżbieta Ostrowska), Crossing New Europe: The European Road Movie (with Laura Rascaroli), Dreams and Diaries: The Cinema of Nanni Moretti, and From Moscow to Madrid: Postmodern Cities, European Cinema. She also co-edited Relocating Britishness. 